The report shows that the project has been slow to get off the ground. In 1960, the ENEA set up a committee to examine the feasibility of the process; in 1961 Austria indicated willingness to do the experimental work, on fruit and fruit juices. In 1962 the draft programme was drawn up; in 1963 a draft agreement was submitted, and it was finally signed in September 1964. Work began in January 1965, but the irradiation facility was not finished until September this year. Initially work will be concentrated on fruit juices, both because of their convenience and because the yeasts which are mainly responsible for the spoilage of fruit juice are a well studied group of micro-organisms. The experimental work is divided into three main fields: radiosensitization studies on yeasts and moulds, technological studies including radiation chemistry and wholesomeness tests.

Like other methods of food preservation-smoking, drying, canning or freezing-irradiation affects the taste of the food. Results at Seibersdorf with grape juice have not yet established which compound is responsible for irradiation taste, but the indications are that the undesirable taste is not caused by protein degradation. Some evidence indicates that flavour changes can be minimized by irradiation at very high dose rates, and preliminary results from work in Switzerland with an accelerator indicate that apple juice can tolerate a high dose rate without significant flavour change. Of rather more importance is the work necessary to establish that the new process is safe for human consumption over long periods. At Seibersdorf animal feeding trials are being made with three types of animals-rats, mice and miniature pigs.

Work with apple juice has established that only one compound, furan or a furan derivative, was specifically produced by the irradiation process. But compounds already present in the unirradiated juice, like acetaldehyde, may be increased. The concentration of acetaldehyde continues to increase during storage, while cupronaldehyde, present after irradiation, appears to decline in concentration during storage. The irradiated apple juice, the report says, could be stored successfully at room temperature for 200 days.

\section{Architects and Engineers}

THE building industry has for a long time been troubled by differences that exist between the members of the various professions that work together in a building team. Architects and engineers have tended to become isolated from one another because of differences in their professional training. An attempt is now being made to find ways of breaking down the barriers between them, so that the skills and total knowledge of individuals can be used more effectively than at present. A joint education group was set up in 1966 by the Council of Engineering Institutions (CEI) and the Royal Institute of British Architects (RIBA) to find ways of improving the understanding during training between the disciplines of architecture and engineering, and to consider the possibility of training people to be both engineers and architects. The nine-strong group of two architects, four engineers and three RIBA staff has just produced its interim report, which covers the first of these problems and gives a preliminary statement of the second.

Much of the present lack of communication between architects and engineers is caused by differences in the educational systems. Both professions require at least six years' training, but the academic content varies. Engineers take a three-year academic course followed by three years' practical training, while architects have a year of practical training after their third year, in the middle of their academic course, so that theory and practice are interwoven. But the most fundamental difference is in the approaches of the professions. Engineers are given highly technical training with little concern for the human side of the problems. Architects, on the other hand, consider the human factor to be of prime importance, but are sometimes short on technical expertise. Some subjects that are common to both disciplines have up to now been treated differently. In structures, for example, architects are concerned with strategy, and engineers with tactics. This means that architects study the causes and effects of certain choices, while engineers are there to see that the choice which is finally made stays up. Despite his greater technical knowledge, the engineer must leave design to the architect.

The problems of communication are not new, but there are now signs of progress. The CEI, which represents the majority of the engineering institutions, is aiming to provide a common theoretical basis for all engineers which can then be applied to any specialist field. This approach does not encourage integration with architecture, but the fact that the CEI is involved on the education project indicates its awareness of the situation. The Council for National Academic Awards, which awards degrees to students at polytechnics, has the power to accept or reject courses into the degree category. It therefore has considerable influence on the content of non-university courses. The group has several suggestions to make for increasing understanding and co-operation, based on the idea of students working together. Project work could be carried out by architecture and engineering students together, and some parts of the syllabus could be shared. The group believes that "orientation" courses for engineers entering the building field are worth investigating. Teachers from one discipline who appreciate the problems of the other could also help. The ultimate solution as described by the group rests on the establishment of educational institutions where architects and building engineers can work together. This would require engineers to commit themselves to the building field at an early stage-to good purpose, the group thinks.

\section{Free Enterprise under the Sea}

AmIDst all the rumours of new Government support for oceanography in Britain, it is refreshing to find some young men who are prepared to back their hunches and build for the future under the sea without waiting for the cat to jump.

At Lintott Engineering Ltd's Horsham works last week, Britain's first mobile submersible was given its first demonstration. Called SURV, for Standard Underwater Research Vessel, it was initially the concept and design of M. J. Borrow, R. E. Lloyd and J. M. Metcalf of Underwater and Marine Operations Ltd (Woking), who have seen it through to the fully engineered prototype constructed by Lintott and demonstrated last week after two months of sea trials. 